\title{
AN INSTRUMENTAL VARIABLES EVALUATION OF THE EFFECT OF ANTIDEPRESSANT USE ON EMPLOYMENT AMONG HIV- INFECTED WOMEN USING ANTIRETROVIRAL THERAPY IN THE UNITED STATES: 1996-2004
}

\author{
Omar Galárraga*, \\ National Institute of Public Health (INSP), Division of Health Economics and University of California, \\ Berkeley, Institute of Business and Economic Research (IBER) \\ David S. Salkever, \\ University of Maryland at Baltimore County (UMBC), Department of Public Policy and National \\ Bureau of Economic Research (NBER)
}

Judith A. Cook, and

University of Illinois at Chicago, Department of Psychiatry

Stephen J. Gange

Johns Hopkins Bloomberg School of Public Health, Department of Epidemiology

\section{SUMMARY}

Depression is a common condition among patients with HIV. This paper uses panel data for 1,234 participants from the Women's Interagency HIV Study (WIHS) to estimate the effect of antidepressant use on the likelihood of being employed among women receiving highly active antiretroviral therapy (HAART) in the United States from 1996 to 2004. We show that naïve regressions of antidepressant use on employment generally result in negative or non-significant coefficients, whereas the instrumental variables approach shows a positive and significant effect of antidepressant use on the employment probability of women living with HIV. We use instrumental variables to predict antidepressant use independently of outcomes; thus, addressing potential biases (e.g., more depressed women are more likely to receive antidepressant treatment, but they are also more likely to be unemployed). The results are consistent for linear (random and fixed effects) as well as non-linear (bivariate probit) specifications. Among women receiving HAART, and

*Correspondence to: Omar Galárraga, Researcher, National Institute of Public Health (INSP), Av. Universidad 655, Cuernavaca, Mexico C.P. 62508, Telephone: +52-777-329-3000 ext. 5409, Fax: +52-777-311-1156, E-mail: ogalarraga@insp.mx or galarraga@haas.berkeley.edu.

Participants' data in this manuscript were collected by the Women's Interagency HIV Study (WIHS) Collaborative Study Group with centers (Principal Investigators) at New York City/Bronx Consortium (Kathryn Anastos); Brooklyn, NY (Howard Minkoff); Washington DC Metropolitan Consortium (Mary Young); The Connie Wofsy Study Consortium of Northern California (Ruth Greenblatt); Los Angeles County/Southern California Consortium (Alexandra Levine); Chicago Consortium (Mardge Cohen); Data Coordinating Center (Stephen Gange). The WIHS is funded by the National Institute of Allergy and Infectious Diseases with supplemental funding from the National Cancer Institute, the National Institute on Drug Abuse (UO1-AI-35004, UO1-AI-31834, UO1-AI-34994, UO1-AI-34989, UO1AI-34993, and UO1-AI-42590). Funding is also provided by the National Institute of Child Health and Human Development (UO1HD-32632) and the National Center for Research Resources (MO1-RR-00071, MO1-RR-00079, MO1-RR-00083). Website located at https://statepiaps.jhsph.edu/wihs/

DISCLOSURE: The authors do not have any personal or financial relationships which may be construed as potential conflicts of interest. The work presented here did not involve human subjects directly; only data analysis. Nevertheless, the research protocol was reviewed and obtained expedited approval by the Institutional Review Board at the Johns Hopkins Bloomberg School of Public Heath.

JEL classification: I12, I18, J22 
controlling for individual and local area labor market characteristics, the use of antidepressants is associated with a 29-percentage-point higher probability of being employed. Improved efforts to test, diagnose and treat depression among HIV-positive patients may improve not only clinical indicators but also labor market outcomes.

\section{Keywords}

antidepressants; employment; HIV/AIDS; antiretroviral treatment; instrumental variables

\section{INTRODUCTION}

Depression treatment has been shown to have an impact on the likelihood of being employed (Schoenbaum et al., 2002) in the general population. Similarly, highly active antiretroviral therapy (HAART) has an important clinical effect, as well as an influence in terms of employment (Goldman and Bao, 2004), among HIV-infected individuals. However, there have been no studies so far evaluating the impact of antidepressant use on the employment for persons living with HIV and using HAART. Conducting this evaluation is important because depression is common, often under diagnosed and under treated in HIV-positive populations (Ciesla and Roberts, 2001; Asch et al., 2003).

To conduct the evaluation in a hypothetical randomized control trial, we would assign depressed HIV-positive patients on HAART to two groups: one group treated with antidepressants and a control group that is not treated with antidepressants. Then, we would compare their employment outcomes after a suitable period of observation. This, of course, would be unethical: knowingly denying necessary medical treatment to patients who need it. The research question then may be best addressed with non-experimental methods, but requires exercising considerable care, because simply comparing treated versus non-treated patients, in a setting where they themselves are in part responsible for seeking and complying with treatment, can result in biased estimates of the treatment effect.

This paper estimates the effect of antidepressant use on the patient's probability of employment using panel data from a sample of women living with HIV and who are using HAART. The analytical approach explicitly takes into account the fact that observable and unobservable factors may play a role in the relationship of interest. We use measures of the variability in Medicaid coverage for antidepressants over time and across states as instrumental variables for the use of antidepressants. This variability is directly related to the patient's likelihood of receiving antidepressant treatment.

\section{BACKGROUND}

The impact of mental health on labor market outcomes has been documented in the literature. A study using nationally representative data (Ettner, Frank, and Kessler, 1997) estimated the effect of several disorders, including major depression, on labor market outcomes. Women with depression were reported to be about eight percentage points less likely to be employed (a reduction in the probability of employment from $81.8 \%$ with no disorder, to $73.7 \%$ in the presence of major depression). A study at a regional level focusing on a low-income population (Alexandre and French, 2001) examined the effect of depression on labor market outcomes in the Miami-Dade County, and found that depression decreased the probability of being employed by 19 percentage points.

In terms of treatment, data from a randomized controlled trial (Schoenbaum et al., 2002) demonstrated that appropriate depression treatment has a positive effect on employment. The 
study found that $72 \%$ of patients exposed to the appropriate depression care were employed six months after treatment; compared to 53\% of those who received no or inappropriate treatment.

\section{CONCEPTUAL FRAMEWORK}

Our conceptual framework for the current analysis is derived from the basic model of labor supply (Killingsworth, 1983) where a person's decision to work is affected by a number of factors including: age, race, education, marital status, the market wage, non-earned income (or assets), personal health status, and the general state of the economy. Particularly for women, the decision to work is also affected by the number of young children living at home, the partner's or spouse's employment status and wages (Killingsworth and Heckman, 1986; Mroz, 1987), as well as her physical and mental health (Ruhm, 1992).

Figure 1 presents an illustrative case for an HIV-positive person. At the end of an asymptomatic period: viral load increases, CD4 count decreases, symptoms of HIV disease appear, and HAART becomes necessary. In this scenario, employment decreases due to physical illness, treatment side effects, and possible depression. The basic hypothesis to be tested is that effective treatment for HIV disease and depression can reverse that trend.

The CD4 cell count and the viral load are HIV-specific health status indicators. The CD4 count indicates how healthy an individual's immune system is, and how far HIV disease has advanced. It helps predict the risk of medical complications and debilitating infections such as pneumonia. The CD4 count is used in combination with the viral load test, which measures the level of HIV in the blood, to determine the staging and outlook of the disease. Studies of these indicators find that they are significantly related to patients' health-related quality of life (Weinfurt et al., 2000).

HAART dramatically altered the natural course of HIV infection. Potent antiretroviral treatment effectively delays the occurrence of the acquired immunodeficiency syndrome (AIDS); and it extends the life expectancy of HIV-positive individuals (Cole et al., 2003; Detels et al., 1998; Palella et al., 1998). The literature confirms that HAART also affects labor market outcomes. Recent works document that HAART users are more likely to be employed, controlling for relevant covariates (Bernell and Shinogle, 2005; Goldman and Bao, 2004). Thus, this study restricts the analysis to those individuals who are currently using HAART to avoid some of the confounding due to the high effectiveness of the potent antiretroviral treatment on employment outcomes.

Our measure of the treatment effect, then, is a comparison of the exposure to HAART plus antidepressants versus HAART alone. The theory is that HAART is effective in stabilizing current health; and that antidepressants have two additional effects in improving employment outcomes. First, a direct channel from antidepressant use to fewer and less severe depression symptoms to improved employment probabilities. Second, an indirect channel by which antidepressant use improves the probability of receipt and adherence to HAART (Cook et al., 2002; Cook et al., 2006; Kleeberger et al., 2004; Li et al., 2005), and thereby further improves health status and employment probability. The overall objective of this paper is to test the hypothesis that the use of antidepressants has an impact on the employment probability of HIV-positive women who use HAART.

\section{DATA AND METHODS}

The Women's Interagency HIV Study (WIHS) is a well characterized cohort that is socially and racially representative of the HIV-positive female population in the United States (Barkan et al., 1998; and https://statepiaps.jhsph.edu/wihs/). WIHS is also the largest U.S.-based 
longitudinal cohort of HIV-infected women. The original cohort consists of participants who were recruited between 1994-1995; follow-up visits are scheduled every six months. The focus of the cohort study is on clinical outcomes, but basic demographic and socio-economic data are also collected. A total of 3,768 women have been enrolled; about $80 \%$ of them are from racial/ethnic minority groups. The study sites are located in: Bronx, NY; Brooklyn, NY; Chicago, IL; Los Angeles, CA; San Francisco, CA; and Washington, DC.

WIHS has a very low rate of attrition due to death and loss to follow up (Hessol et al., 2001; Kirstein et al., 2002). Study attrition since 1994 among the seropositive women in WIHS was due to 320 deaths and 52 dis-enrolments (Hessol et al., 2001). Cumulative retention rates for WIHS through visit 24 (September 30, 2006) are 74 percent for seronegatives (SN) and 79 percent for seropositives (SP). The majority of dropout in the study occurred at early study visits; for the first 10 study visits that occurred during a 5-year period between 1994 and 1999, the retention rate of participants was approximately 82 percent. The retention rates for WIHS recruits during WIHS III (October 2002-2006) have been very high: 94 percent of SN and 95 percent of SP who were active as of the beginning of WIHS III have been retained. Retention of 2001/02 recruits has outpaced retention of 1994/95 recruits and remains high: 86 percent among SP and 86 percent among SN women. An analysis of HAART using patterns reveals that only 11.4 percent of the women were found to discontinue therapy altogether (Kirstein $e t$ al. 2002).

The present analysis uses WIHS data collected from April 1 ${ }^{\text {st }}, 1996$ (when protease inhibitors (PIs) first became commercially available) through September 30th, 2004. ${ }^{1}$ Women eligible for this study were: HIV-positive, between the ages of 18 and 65 years; for each observation analyzed they had been using HAART ${ }^{2}$ since the previous calendar visit; and had a CES-D of at least 16 at baseline. ${ }^{3}$ A total of 1,234 women fulfilled all these eligibility criteria at baseline. They contributed a total of 12,587 person-visits and had a median follow-up time of 3.5 years. The dependent variable in this paper is a dichotomous indicator of whether the participant is employed at the current visit; and the main explanatory variable is a dichotomous indicator of whether the participant has taken antidepressants since the last visit.

We undertook several analyses. First, we applied a linear probability model using a binary outcome and a binary treatment variable (Angrist, 2001; Heckman, 1978; Heckman and MaCurdy, 1985). The empirical equations in this framework were:

$$
Y_{i t}=\alpha_{i}+\beta_{i} T_{i t}+\gamma X_{i t}+\varepsilon_{i t}
$$

\footnotetext{
${ }^{1}$ Some information about the cohort is lost in this design. However, because of the remarkable effect of HAART, the effect of antidepressant use on employment before 1996 would be completely eclipsed by the HAART effects. Patient follow-up would be very limited because after an asymptomatic period, the health of HIV positive patients declined very rapidly, and the vast majority of patients died. Hence, most studies on this topic focus exclusively on the time period following the introduction of HAART both in the WIHS cohort (e.g., Cook et al 2002 and 2006) and other cohorts (Ghani et al 2003).

2 The definition of HAART in the WIHS was guided by the DHHS/Kaiser Panel (DHHS/KFF 2005) guidelines and defined as: (a) two or more nucleoside or nucleotide reverse transcriptase inhibitor (NRTIs) in combination with at least one protease inhibitor (PI) or one non-nucleoside reverse transcriptase inhibitor (NNRTI) (88\% of WIHS observations classified as HAART); (b) one NRTI in combination with at least one PI and at least one NNRTI (5\%); (c) a regimen containing ritonavir and saquinavir in combination with one NRTI and no NNRTIs (1\%); and (d) an abacavir or tenofovir containing regimen of three or more NRTIs in the absence of both PIs and NNRTIs (6\%), except for the three-NRTI regimens consisting of: abacavir + tenofovir + lamivudine OR didanosine + tenofovir + lamivudine. Combinations of zidovudine (AZT) and stavudine (d4T) with either a PI or NNRTI were not considered HAART. The most frequent case of monotherapy was of one NRTI (92\%). Of the other monotherapy cases, taking only PIs accounted for 6\%; while taking only NNRTIs accounted for $2 \%$. All other ART regimens were classified as combination therapy. The three most frequent cases of combination therapy were: (a) only two NRTIs (67\%); (b) three or more NRTIs without abacavir or tenofovir and in the absence of PIs and NNRTIs $(11 \%)$; and (c) at least one PI and at least one NNRTI in the absence of NRTI (4\%).

${ }^{3}$ This investigation uses the Center for Epidemiologic Studies-Depression scale (CES-D) to assess depression symptoms (Radloff 1977). The scale ranges from zero to 60. A cutoff at or above 16 indicates "probable cases of depression".
} 


$$
T_{i t}=\delta_{i}+\theta X_{i t}+\phi Z_{i t}+v_{i t}
$$

where for individual $i$ at time $t, Y$ is the outcome of interest (current employment), $T$ is the treatment variable (antidepressant use since the previous visit), $X$ is the covariates vector, $Z$ are instrumental variables, and $\varepsilon$ and $v$ are error terms. Under the random effects (RE) model, the individual-specific term $\alpha_{i}$ is assumed to be uncorrelated to the covariates vector $X$, so that the conditional distribution $f(\alpha \mid X)$ is not dependent on $X$. On the other hand, the fixed effects (FE) model leaves that distribution unrestricted, so that $\alpha$ and $X$ may be correlated (Greene, 2003). That is, in the FE model we assumed that equations (1) and (2) contain fixed effects for each individual, which can potentially be correlated with $T_{i}$ but that cancel out with the subtraction of the time-averaged model (yielding the "within" or fixed effects estimator).

In the empirical estimation, under $\mathrm{FE}$, the $X$ vector contains the following time-varying variables: CD4 cell count, detectable viral load (=1 if HIV RNA level is greater than 80 copies per $\mathrm{ml} ;=0$ otherwise), the depression symptoms score (CES-D), as well as a general quality of life index. ${ }^{4}$ In addition, $X$ contains labor market characteristics measured at the local level: including the unemployment rate $^{5}$, and average real weekly earnings at the Metropolitan Statistical Area (MSA) level ${ }^{6}$, and the adult employment ratio at the State level ${ }^{7}$. The hypothesized channels for the treatment effect work through the CES-D, quality of life index, CD4 cell count and detectable viral load; thus, these variables were used at their previous calendar period levels to avoid endogeneity from antidepressant use (since last visit) into current-period health status measures. We used those health status variables at the previous time in both equations because previous health status affects both the probability of current treatment and of current employment (due to productivity, physical and emotional strength).

Under RE, in addition to the time-varying control variables detailed above, $X$ contains the following variables: age at visit; age squared; dummy variables for participants who are: high school graduate, African American, Hispanic, have a partner/spouse living at home; the number of children (age 18 or less) living with the participant; and dummy indicators for the participant's site.

In a second set of analyses, given that both the outcome and treatment variables are dichotomous indicators, we also used a non-linear model: the bivariate probit model (Maddala, 1983). In the bivariate probit specification, the assumption was that both employment and antidepressant use were determined by an underlying continuous function indexes $\left(Y^{*}\right.$ and $\left.T^{*}\right)$. When $Y^{*}$ or $T^{*}$ have values above zero (for normalization purposes), the corresponding observable outcome (employment $=Y$ or antidepressant use $=T$ ) takes a value of the unity, and it is zero otherwise. The main equations (1) and (2) presented above remain as before, but now we assumed a bivariate normal distribution for the error terms (with the variance normalized to the unity and the correlation coefficient denoted as $\rho$ ) in the following manner:

\footnotetext{
${ }^{4}$ To complement clinical indicators of disease progression (CD4 and viral load), we use a multi-item scale as a proxy for productivityrelated measures: the quality of life index (Bozzette et al. 1995).

${ }^{5}$ Unemployment data come from the Local Area Unemployment Statistics (LAUS) program which produces monthly and annual employment, unemployment, and labor force data for Census regions and divisions, States, counties, metropolitan areas, and many cities, by place of residence (Bureau of Labor Statistics 2005b).

6 Average earnings for the relevant Metropolitan Statistical Areas (MSAs) come from the Current Population Survey (CPS), a monthly household survey conducted by the Bureau of the Census (Bureau of Labor Statistics 2005a).

${ }^{7}$ To control for discouraged workers (i.e., those who are no longer in the labor force because they are not working, and they are not looking for a job), we constructed a measure of adult employment at the State level. This measure is the ratio of the employed over the total non-institutionalized civilian population aged 16 and over (NCP16+) (regardless of whether they are in the labor force or not). We used The Geographical Profile of Employment and Unemployment series that reports the NCP16+ at the State level on a yearly basis (Bureau of Labor Statistics (various years), and Bureau of Labor Statistics 2005b).
} 


$$
\left(\begin{array}{l}
\varepsilon \\
v
\end{array}\right) \sim B V N\left(\left[\begin{array}{l}
0 \\
0
\end{array}\right],\left[\begin{array}{ll}
1 & \rho \\
\rho & 1
\end{array}\right]\right)
$$

The correlation between $\varepsilon$ and $v$ captures the correlation between the likelihood of being employed and the propensity of taking antidepressants. A positive correlation coefficient would indicate that patients who take antidepressants are more likely to work; while a negative $\rho$ would indicate that those using antidepressants are less likely to be working. The model was identified with the use of instrumental variables. Marginal effects of antidepressant use on the employment outcomes of the HIV-infected women were estimated as the differences between the two mean employment outcomes within each scenario: with and without antidepressant use.

For all model specifications, we compared the results from "naïve" estimates where antidepressant use was assumed to be exogenous, to the results we obtained using instrumental variables. Analyses were conducted using STATA ${ }^{\mathrm{TM}}$ (Statistical Data Analysis, Special Edition, Version 9.3, College Station, Texas), including the ivreg2, xtivreg2, and biprobit ado files (Baum et al., 2007; Schaffer, 2007).

\section{Instrumental Variables}

Estimating the employment effect of antidepressant use was complicated by endogeneity: as individuals present more symptoms of depression (and as the CES-D score increases), the probability of receiving antidepressants was also likely to increase. However, at the same time, more depressed persons were also more likely to be jobless because of socio-economic, demographic, local area or other characteristics. The literature suggests that unemployment is a risk factor for depressive status. ${ }^{8}$ In addition, there was another potential endogeneity issue as the probability of employment may affect health insurance status, which in turn may affect the likelihood of obtaining antidepressant treatment. ${ }^{9}$

To address these issues, we used an instrumental variables approach (Angrist and Krueger, 2001), which has been applied widely (Angrist, Imbens, and Rubin, 1996; Greenland, 2000; Harris and Remler, 1998; Moffitt, 2005; Newhouse and McClellan, 1998); including in the mental health economics literature (Crown et al., 1998; Lu, 1999; Salkever et al., 2004; Salkever, Slade, and Karakus, 2006). The method requires that the instruments be highly correlated with the treatment choice; but cannot have direct effect on the outcome (Cameron and Trivedi, 2005; Greene, 2003; Wooldridge, 2002).

We used two instruments: the volume of Medicaid prescriptions claims for selective serotonin reuptake inhibitors (SSRIs) as percentage of total volume of Medicaid antidepressant prescriptions; and the volume of SSRI prescription claims per Medicaid beneficiary $(\times 100)$ (both at the state level). The instrumental variables were constructed on a quarterly basis for the years 1996-2004 at the state level; and then assigned to each individual's visit observation for participants in the WIHS cohort according to the relevant state and visit date. The Centers for Medicaid and Medicare Services (CMS) define the number of prescriptions in each state data file as "the number of prescriptions reimbursed to pharmacists for the drug for the quarter

\footnotetext{
${ }^{8}$ The literature on the health impacts of unemployment is vast. A number of individual studies and literature reviews confirm that unemployment, inadequate employment and the general economic status of the place of residence affect mental health and depression status (Fone et al 2007; Dooley et al 2000; Wilson and Walker 1993).

${ }^{9}$ Eligibility rules for Medicare and Medicaid might suggest that employment is negatively related to insurance coverage. The reverse might be true for private insurance, though the numbers of persons with such coverage in the WIHS cohort are relatively small (about $9 \%$ of participants reported to have private insurance at baseline; and $12.4 \%$ reported to do so over the entire observation period).
} 
covered" (Centers for Medicaid and Medicare Services, 2005). Beneficiary information was obtained from the Medicaid Statistical Information System (MSIS, 2005).

The rationale to use these instruments was that participants would have a higher chance of receiving antidepressants in states where SSRI diffusion was more rapid; SSRI prescriptions per Medicaid beneficiary are used here as an indicator of that diffusion. As SSRI prescriptions per Medicaid beneficiary increased, the likelihood that the participants received treatment also would increase. The "diffusion" rationale has been used for other mental health treatment analyses, particularly for newer treatments for schizophrenia (Domino, Frank, and Rosenheck, 2003; Salkever et al., 2004; Salkever, Slade, and Karakus, 2006). Duggan (2005) is another example of a similar approach to generating an instrument for drug use by exploiting the variation across geographic areas in the diffusion of second-generation anti-psychotics. Our selection of IVs was driven by our intention to measure depression treatment using an indicator that was not directly related to our dependent variable of employment. We assumed that the likelihood of depression treatment would be greater for residents of states in which Medicaid paid for more SSRI prescriptions per patient. Note, however, that the Medicaid SSRI instrument would primarily reflect variability in diffusion of SSRIs to prescribers rather than variations in implementation of formulary restrictions or in extent of financial coverage. WIHS participants in states with higher diffusion would be more likely to be receiving SSRIs for depression. Nevertheless, the higher chance of receiving SSRI treatment would not to be correlated with the probability of employment, given that the IV is a measure at the level of the state rather than at the individual level. That is, there was no reason to expect a high correlation between states with more rapid SSRI diffusion and the probability of employment for WIHS participants at the individual level.

\section{RESULTS}

We first describe the WIHS sample in Table 1, which shows the descriptive statistics. At baseline, (defined as the first visit for which a participant was on HAART since the last calendar visit; and had a CES-D score of at least 16, i.e., the usual cutoff for "probable depression"), a fourth of the participants were employed and $17.6 \%$ of the participants were taking antidepressants. Although 59.9\% of the participants had finished high school, only 5.4\% completed four years of college. The predominant racial group of the sample was African American (52.8\%), followed by Hispanic (29.6\%), and then Caucasian (14.7\%). About $60 \%$ of participants reported an annual household income of less than $\$ 12,000$ per year; $63.4 \%$ reported public health insurance through Medicaid (or Medi-Cal for California residents); and $11 \%$ reported Medicare. About $63 \%$ of participants had a detectable level of viral load (above 80 copies of HIV RNA per ml). WIHS participants in this sample were distributed across the six study sites as follows: Bronx, NY (21.4\%); Brooklyn, NY (14\%); Washington, DC (14.2\%); Los Angeles, CA (21.7\%); San Francisco, CA (13.9\%); and Chicago, IL (14.8\%).

The mean age of the participants at baseline was 38.4 years. Participants had an average of 0.3 minor children (ages 18 or younger) living at their home (with a range from zero to 10). The mean CES-D (depression score) at baseline was 26.3 (which is well above the cutoff of 16 that is likely to agree with a diagnosis of depression). The average quality of life index was 55.5; and the average CD4+ cell count of 395. In terms of constructed variables: at the Metropolitan Statistical Area (MSA) level, the unemployment rate stood at 5.4\%, and the mean earnings were $\$ 391$ per week; at the State level, 62\% of the non-institutionalized population (16 years and over) were employed. The instrumental variables (volume of SSRI prescriptions as percentage of total volume of Medicaid antidepressant prescriptions, and SSRI prescriptions per Medicaid beneficiary times 100) had means of 43.3 and 6.5. 
Second, we assessed whether the IVs are good instruments for antidepressant use. Table 2 shows the first stage linear regression models for the probability of using antidepressants as a function of the IVs (volume of SSRI prescriptions as percentage of total volume of Medicaid antidepressant prescriptions, and SSRI prescriptions per Medicaid beneficiary) and all other covariates. The IV coefficients are of the expected sign (positive) and significant. For example, the 0.0041 for first instrument shows that the mean difference in probability of use of antidepressants is positive and significant in a multivariate random effects model. The tests of excluded instruments suggest that our IVs are good predictors of whether or not the participants are using antidepressants. The $F$ statistic of excluded instruments in the fixed effects model was 22.18; and it was 40.08 under the random effects model. These results were well above the rule-of-thumb $F$ statistic suggested in the literature to avoid the problem of weak instruments (Staiger and Stock, 1997). In addition, the test for overidentification, suggested in Davidson and MacKinnon (1993), yielded a $p$-value of 0.664 thus indicating that the data do not reject the assumption that the only manner in which the instruments (SSRI prescriptions over total Medicaid antidepressant prescriptions and SSRI Medicaid prescriptions filled per beneficiary) affect the individual level employment probability is through their effect on antidepressant use patterns.

Third, we formally tested for the endogeneity of antidepressant use in the employment equation. Using the predicted residuals from the regressions in Table 2, we ran linear regression of employment on a constant, antidepressant use, the first stage predicted residuals, and all of the covariates (Hausman, 1978). We found that under both random effects and fixed effects specifications the predicted residuals were negative and significant. Thus, unobserved components in the first stage do seem to influence the main outcome, lending credibility to the hypothesis of endogeneity. In addition, in the non-linear specification model (Table 4), we present the results of the bivariate probit estimations, including the value of the coefficient of correlation $(\rho)$ which was negative and also significant, suggesting again that antidepressant use is endogenous.

Table 3 shows linear models for the probability of employment, under the fixed effects and random effects assumptions. These models account for the endogeneity of antidepressant use using an IV approach (Heckman, 1978). After adjusting for personal (demographic, socioeconomic and clinical) characteristics, as well as other local labor market conditions, we found that probably-depressed women who used antidepressants had a higher probability of being employed than those who did not use antidepressants. This finding was statistically significant under the random effects, and also under the fixed effects models.

The first column in Table 3 shows results from a "naïve" RE model, where the antidepressant use coefficient was slightly positive with a coefficient of 0.01 , but it was not significant. On the other hand, in the second column, we used the instrumental variables and found that effect of antidepressants on employment was 0.42 and significant. Similarly, a naïve OLS with FE (third column) gave a slightly positive coefficient of 0.03 , whereas the coefficient of antidepressant use on employment (fourth column) was about 0.30 and significant in the FE addressing the endogeneity with IV.

Six other factors in the RE model were associated with higher employment probabilities: high school graduation, the quality of life index, CD4 cell count and being a participant in the Washington, DC site (as compared to Chicago, IL, the reference site). The following variables affected negatively the likelihood of employment: being African American and study site in Bronx, NY. In the FE model, higher employment was associated with: higher quality of life index and higher CD4 cell count. 
Table 4 shows the results of two non-linear models of employment probability: a naïve probit, and a bivariate probit model using instrumental variables. In the naïve probit model, the coefficient of antidepressant use on employment was 0.05 with a marginal effect of 0.01 and not significant. On the other hand, using instrumental variables to identify a bivariate probit model, we found that the coefficient of antidepressant use on employment was 0.80 with a marginal effect of 0.28 and significant.

\section{DISCUSSION}

The results, under the preferred linear fixed effects model as well as the bivariate probit model, show that the probability of being employed is about 29 percentage points higher for a (probably-depressed, HIV-positive, HAART-compliant) participant who used antidepressants compared to one who did not. That is, starting from an average predicted employment probability of $20 \%$, antidepressant use increased that probability to $49 \%$. In contrast, the assumption that treatment is exogenous (in naïve regressions) resulted in coefficients that were negative, or just slightly positive.

This paper shows that instrumental variables (IV) based on the volume of the Medicaid SSRI prescriptions at the State level can be used to identify a positive effect of antidepressant use on the employment probability. The instrumental variables capitalize on the variation in Medicaid coverage for antidepressants across states and over time, and are thus strong predictors of treatment likelihood. As diffusion of the newer class of antidepressants (selective serotonin reuptake inhibitors or SSRIs) increases, the likelihood of an individual person in the sample to use antidepressants also increases, controlling for other relevant predictors of treatment. ${ }^{10}$

Our estimates of the treatment effect seem to be generally in agreement with, though slightly higher than, previous results in the literature. Schoenbaum et al., (2002) find an almost 20 percentage point difference ( $72 \%$ for the treatment group vs. 53\% for the control) in the probability of employment between standard vs. appropriate depression care in a randomized controlled trial. Some possible explanations for the findings are as follows. First, women in the WIHS sample are of low socio-economic and health status; thus HAART plus pharmacological depression treatment may have a stronger effect for this population. As general health status improves, and as individuals are more likely to be working, there may be a diminishing antidepressant effect on employment. Second, and more importantly, the effects found maybe larger than previous interventions because of the interactions between the direct effect (through mental health status), and the indirect effect (through HAART adherence); hence, resulting in important implications for clinical practice and policy.

Our study has some limitations. WIHS data in general are of very high quality; an important characteristic of the WIHS cohort is that it has centralized staff training, standardized data collection and processing procedures, and quality assurance monitoring for each participating center (Barkan et al. 1998). Nevertheless, the labor market data obtained is only partial. We do not capture labor force participation because the labor force includes both the employed and those looking for work; and WIHS questionnaires do not ask whether unemployed participants are looking for a job. We do explore, however, the influence of private and public health insurance in sensitivity analyses, and the results are robust to including previous period health insurance status in the current period employment equation. ${ }^{11}$

\footnotetext{
${ }^{10}$ Note that a (remote) possibility might exist that the availability of SSRIs may encourage some study individuals to become (or remain) unemployed so they could continue to receive Medicaid coverage; however, if such an effect existed, it would tend to cause a negative correlation between the instrument and the employment dependent variable.
} 
Second, we have no evidence that the women are adherent/compliant to their antidepressant medication regimen (only that they report having a prescription or taking it at some point); thus there may be a possibility for misclassifying some participants as having had treatment when in fact they did not have it. Nevertheless, if that was the case, our current estimates would be biased downwards towards zero, or towards "no effect." Also, the dichotomous variable of antidepressant use as a measure of anti-depression treatment is rudimentary: there is no data about how long participants have been taking the antidepressants (within visits), or the doses taken. Third, the two hypothesized channels as to how the effect of antidepressant use works on employment need to be determined more specifically. Future research can test how much of the employment effect is working through mental health status, and how much of the effect is working through increased adherence to HAART, and hence better overall physical health. Finally, the IVs may not provide a fully unconfounded estimate of the treatment effect. As with other IV estimates, ours provide only a local average treatment effect, or LATE (Imbens and Angrist 1994), in the sense that it applies exclusively to those participants for which the IV has an effect on actual treatment. We chose to include in the present analysis only the IVs that worked best (SSRI prescriptions over total Medicaid antidepressant prescriptions, and SSRI prescriptions per Medicaid beneficiary). Other IVs that we tried (but are not using in this analysis) were less powerful in explaining treatment choice: Antidepressant prescriptions over total Medicaid prescriptions; antidepressant prescriptions per Medicaid beneficiary; antidepressant prescriptions per adult Medicaid beneficiary; SSRI prescriptions per adult Medicaid beneficiary.

In conclusion, the findings suggest that the use of antidepressants improves the employment outcomes for the women in the Women's Interagency HIV Study (WIHS), and it may do so for a probably-depressed segment of the HIV-positive women in the U.S. Increased and continued support for the inclusion of antidepressants in programs such as the AIDS Drugs Assistance Program (ADAP), Ryan White CARE Act, and Medicaid formularies may be warranted for specific population groups, particularly low-income women, not only based on improved medical outcomes, but also based on potential employment effects.

\section{Acknowledgments}

We are grateful for comments from Robert Moffitt, Alvaro Muñoz, Darrell Gaskin, and two anonymous referees. We also acknowledge detailed discussions with Cynthia Perry, Jalpa Doshi, Eric Slade, Mustafa Karakus, and various participants at presentations at: American Economic Association (AEA), Academy Health Research Meetings (Health Economics Interest Group); American Society of Health Economists (ASHE); International Health Economics Association (iHEA), Johns Hopkins University (Health Economics Seminar); Mathematica Policy Research, National Institute of Public Health/Mexican School of Public Health, and RAND Corporation. The authors report no conflicts of interest; they are solely responsible for the contents.

Research funding provided by a pre-doctoral fellowship in Mental Health Economics from the U.S. National Institute of Mental Health (NIMH) (for OG) through the Johns Hopkins Bloomberg School of Public Health. Partial support for writing this paper was also provided by the U.S. National Institutes of Health (NIH)/Fogarty International Center (K01-TW008016-01, PI: Omar Galárraga).

\footnotetext{
${ }^{11}$ Current period private and public health insurance status are likely to be endogenous in the current period employment equation. Thus, we conducted sensitivity analyses with previous-period Medicaid and Medicare status variables: the main results presented in this paper did not change. Similarly, we analyzed the issue of private health insurance: the coefficient of private health insurance (at $t-1$ ) was significantly positive in the current period employment model with random effects, controlling for all the covariates, including Medicare and Medicaid (both at $t-1$ ). However, private health insurance (at $t-1$ ) was not significant in the current period employment model with fixed effects. The main results of the paper were robust for all the models tested: using an IV approach, and controlling for insurance status, antidepressant use was a positive and significant determinant of current period employment. The coefficients were of similar magnitude as those we found in the main analysis (results not shown).
} 


\section{References}

Alexandre PK, French MT. Labor Supply of Poor Residents in Metropolitan Miami, Florida: The Role of Depression and the Co-Morbid Effects of Substance Use. Journal of Mental Health Policy and Economics 2001;4(4):161-173. [PubMed: 12119426]

Angrist JD. Estimations of Limited Dependent Variable Models with Dummy Endogenous Regressors: Simple Strategies for Empirical Practice. Journal of Business and Economic Statistics 2001;19(1):216.

Angrist JD, Imbens GW, Rubin DB. Identification of Causal Effects using Instrumental Variables. Journal of the American Statistical Association 1996;91(434):444-455.

Angrist JD, Krueger AB. Instrumental Variables and the Search for Identification: From Supply and Demand to Natural Experiments. Journal of Economic Perspectives 2001;15(4):69-85.

Asch SM, Kilbourne AM, Gifford AL, Burnam MA, Turner B, Shapiro MF, Bozzette SA. HCSUS Consortium. Underdiagnosis of Depression in HIV: Who Are We Missing? Journal of General Internal Medicine 2003;18(6):450-460. [PubMed: 12823652]

Barkan SE, Melnick SL, Preston-Martin S, Weber K, Kalish LA, Miotti P, Young M, Greenblatt R, Sacks H, Feldman J. The Women's Interagency HIV Study: WIHS Collaborative Study Group. Epidemiology (Cambridge, Mass) 1998;9(2):117-125.

Baum, CF.; Schaffer, ME.; Stillman, S. IVREG2: STATA Module for Extended Instrumental Variables/ 2SLS, GMM and AC/HAC, LIML and K-class Regression. 2007 [[7 May 2007]]. http://ideas.repec.org/c/boc/bocode/s425401.html/

Bernell SL, Shinogle JA. The Relationship between HAART Use and Employment for HIV-Positive Individuals: An Empirical Analysis and Policy Outlook. Health Policy (Amsterdam, Netherlands) 2005;71(2):255-264.

Bozzette SA, Hays RD, Berry SH, Kanouse DE, Wu AW. Derivation and Properties of a Brief Health Status Assessment Instrument for use in HIV Disease. Journal of Acquired Immune Deficiency Syndromes and Human Retrovirology 1995;8(3):253-265. [PubMed: 7859137]

Bureau of Labor Statistics. Current Population Survey Website. 2005a [[17August 2005]]. http://www.bls.gov/cps/home.htm/

Bureau of Labor Statistics. Local Area Unemployment Website. 2005b [[7 September 2005]]. http://www.bls.gov/lau/home.htm

Bureau of Labor Statistics. (Various years). Geographical Profile of Employment and Unemployment, 1996-2004. Washington, D.C.: Bureau of Labor Statistics;

Cameron, AC.; Trivedi, PK. Microeconometrics: Methods and Applications. New York, NY: Cambridge University Press; 2005.

Centers for Medicaid and Medicare Services. Medicaid Drug Utilization Information for Outpatient Drugs Purchased on or after January 1, 1991, by State Medicaid Agencies, Website. 2005. http://www.cms.hhs.gov/medicaid/drugs/drug5.asp/[14 May 2005]

Ciesla JA, Roberts JE. Meta-Analysis of the Relationship between HIV Infection and Risk for Depressive Disorders. The American Journal of Psychiatry 2001;158(5):725-730. [PubMed: 11329393]

Cole SR, Hernan MA, Robins JM, Anastos K, Chmiel J, Detels R, Ervin C, et al. Effect of Highly Active Antiretroviral Therapy on Time to Acquired Immunodeficiency Syndrome Or Death using Marginal Structural Models. American Journal of Epidemiology 2003;158(7):687-694. [PubMed: 14507605]

Cook JA, Cohen MH, Burke J, Grey D, Anastos K, Kirstein L, Palacio H, Richardson J, Wilson T, Young M. Effects of Depressive Symptoms and Mental Health Quality of Life On Use of Highly Active Antiretroviral Therapy among HIV-Seropositive Women. Journal of Acquired Immune Deficiency Syndromes 2002;30(4):401-409. [PubMed: 12138346]

Cook JA, Grey D, Burke-Miller J, Cohen MH, Anastos K, Gandhi M, Richardson J, Wilson T, Young M. Effects of Treated and Untreated Depressive Symptoms On Highly Active Antiretroviral Therapy Use in a U.S. Multi-Site Cohort of HIV-Positive Women. AIDS Care 2006;18(2):93-100. [PubMed: 16338766]

Crown WH, Obenchain RL, Englehart L, Lair T, Buesching DP, Croghan T. The Application of Sample Selection Models to Outcomes Research: The Case of Evaluating the Effects of Antidepressant 
Therapy on Resource Utilization. Statistics in Medicine 1998;17(17):1943-1958. [PubMed: 9777688]

Davidson, R.; MacKinnon, J. Estimation and Inference in Econometrics. Oxford: Oxford University Press; 1993.

Detels R, Muñoz A, McFarlane G, Kingsley LA, Margolick JB, Giorgi J, Schrager LK, Phair JP. Effectiveness of Potent Antiretroviral Therapy on Time to AIDS and Death in Men with Known HIV Infection Duration. JAMA 1998;280(17):1497-1503. [PubMed: 9809730]

Dooley D, Prause J, Ham-Rowbottom KA. Underemployment and depression: longitudinal relationships. Journal of Health and Social Behavior 2000;41(4):421-36. [PubMed: 11198566]

Duggan M. Do New Prescription Drugs Pay for Themselves? The Case of Second-Generation Antipsychotics. Journal of Health Economics 2005;24:1-31. [PubMed: 15617786]

DHHS/KFF. Guidelines for the Use of Antiretroviral Agents in HIV-Infected Adults and Adolescents. National Institutes of Health/DHHS/Henry J. Kaiser Family Foundation; 2006 [[7 May 2006]]. http://aidsinfo.nih.gov/ContentFiles/AdultandAdolescentGL.pdf/

Domino ME, Frank RG, Rosenheck R. The Diffusion of New Antipsychotic Medications and Formulary Policy. Schizophrenia Bulletin 2003;29(1):95-104. [PubMed: 12908664]

Ettner SL, Frank RG, Kessler RC. The Impact of Psychiatric Disorders on Labor Market Outcomes. Industrial and Labor Relations Review 1997;51(1):64-81.

Fone D, Dunstan F, Williams G, Lloyd K, Palmer S. Places, people and mental health: a multilevel analysis of economic inactivity. Social Science and Medicine 2007;64(3):633-45. [PubMed: 17070974]

Ghani AC, Donnelly CA, Anderson RM. Patterns of antiretroviral use in the United States of America: analysis of three observational databases. HIV Medicine 2003;4(1):24-32. [PubMed: 12534956]

Goldman DP, Bao Y. Effective HIV Treatment And The Employment of HIV+ Adults. Health Services Research 2004;39(6):1691-1712. [PubMed: 15533182]

Greene, WH. Econometric Analysis. Upper Saddle River, NJ: Prentice Hall; 2003.

Greenland S. An Introduction To Instrumental Variables For Epidemiologists. International Journal of Epidemiology 2000;29(4):722-729. [PubMed: 10922351]

Harris KM, Remler DK. Who Is The Marginal Patient? Understanding Instrumental Variables Estimates Of Treatment Effects. Health Services Research 1998;33(5 Pt 1):1337-1360. [PubMed: 9865223]

Hausman JA. Specification Tests in Econometrics. Econometrica 1978;46(6):1251-1271.

Heckman JJ. Dummy Endogenous Variables in A Simultaneous Equation System. Econometrica 1978;46 (4):931-959.

Heckman JJ, MaCurdy TE. A Simultaneous Equations Linear Probability Model. Canadian Journal of Economics 1985;18(1):28-37.

Hessol NA, Schneider M, Greenblatt RM, Bacon M, Barranday Y, Holman S, et al. Retention of Women Enrolled in a Prospective Study of Human Immunodeficiency Virus Infection: Impact of Race, Unstable Housing, and Use of Human Immunodeficiency Virus Therapy. American Journal of Epidemiology 2001;154 (6):563-573. [PubMed: 11549562]

Imbens GW, Angrist JD. Identification and Estimation of Local Average Treatment Effects. Econometrica 1994;62(2):467-476.

Killingsworth, MR. Labor Supply. Cambridge and New York: Cambridge University Press; 1983.

Killingsworth, MR.; Heckman, JJ. Female Labor Supply: A Survey. In: Ashenfelter, O.; Layard, R., editors. Handbook of Labor Economics. Vol. 1. New York: Elsevier Science; 1986. p. 103-204.

Kirstein LM, Greenblatt RM, Anastos K, Levine A, French AL, Minkoff H, Silver S, Gange SJ. Women's Interagency HIV Study Collaborative Research Group. Prevalence and Correlates of Highly Active Antiretroviral Therapy Switching in the Women's Interagency HIV Study. Journal of Acquired Immune Deficiency Syndrome 2002;29(5):495-503.

Kleeberger CA, Buechner J, Palella F, Detels R, Riddler S, Godfrey R, Jacobson LP. Changes in Adherence to Highly Active Antiretroviral Therapy Medications in the Multicenter AIDS Cohort Study. AIDS (London, England) 2004;18(4):683-688. 
Li X, Margolick JB, Conover CS, Badri B, Riddler SA, Witt MD, Jacobson LP. Interruption and Discontinuation of Highly Active Antiretroviral Therapy in the Multicenter AIDS Cohort Study. Journal of Acquired Immune Deficiency Syndromes 2005;38(3):320-328. [PubMed: 15735452]

Lu M. The Productivity of Mental Health Care: An Instrumental Variable Approach. Journal of Mental Health Policy and Economics 1999;2(2):59-71. [PubMed: 11967410]

Maddala, GS. Limited Dependent And Qualitative Variables in Econometrics. Cambridge, U.K.: Cambridge University Press; 1983.

Medicaid Statistical Information System (MSIS). State Summary Datamart (SSD): Beneficiary Data Website. 2005 [[7 June 2005]]. http://bizapps.cms.hhs.gov/msis/

Moffitt RA. Remarks on the Analysis of Causal Relationships in Population Research. Demography 2005;42(1):91-108. [PubMed: 15782897]

Mroz TA. The Sensitivity of an Empirical Model of Married Women's Hours of Work to Economic and Statistical Assumptions. Econometrica 1987;55(4):765-799.

Newhouse JP, McClellan M. Econometrics in Outcomes Research: The Use of Instrumental Variables. Annual Review of Public Health 1998;19:17-34.

Palella FJ, Delaney KM, Mooman AC, Loveless MO, Fuhrer J, Satten GA, Aschman DJ, Holmberg SD. Declining Morbidity And Mortality Among Patients With Advanced Human Immunodeficiency Virus Infection. The New England Journal of Medicine 1998;338(13):853-860. [PubMed: 9516219]

Radloff LS. The CES-D Scale: A Self-Report Depression Scale for Research in the General Population. Applied Psychological Measurement 1977;1(3):385-401.

Ruhm, CJ. The Effects of Physical and Mental Health on Female Labor Supply. In: Frank, RG.; Manning, WG., editors. Economics and Mental Health. Baltimore and London: Johns Hopkins University Press; 1992. p. 152-181.

Salkever DS, Slade EP, Karakus M. Differential Effects of Atypical Versus Typical Antipsychotic Medication on Earnings of Schizophrenia Patients: Estimates from a Prospective Naturalistic Study. PharmacoEconomics 2006;24(2):123-139. [PubMed: 16460134]

Salkever DS, Slade EP, Karakus M, Palmer L, Russo PA. Estimation of Antipsychotic Effects on Hospitalization Risk in a Naturalistic Study with Selection on Unobservables. The Journal of Nervous and Mental Disease 2004;192(2):119-128. [PubMed: 14770056]

Schaffer, ME. XTIVREG2: STATA Module to Perform Extended IV/2SLS, GMM and AC/HAC, LIML and K-class Regression for Panel Data Models. 2007 [[7 May 2007]]. http://ideas.repec.org/c/boc/bocode/s456501.html/

Schoenbaum M, Unützer J, McCaffrey D, Duan N, Sherbourne C, Wells KB. The Effects of Primary Care Depression Treatment on Patients' Clinical Status and Employment. Health Services Research 2002;37(5):1145-1158. [PubMed: 12479490]

Staiger D, Stock JH. Instrumental Variables Regression with Weak Instruments. Econometrica 1997;65 (3):557-586.

Weinfurt KP, Willke RJ, Glick HA, Freimuth WW, Schulman KA. Relationship Between CD4 Count, Viral Burden, and Quality of Life Over Time in HIV-1-Infected Patients. Medical Care 2000;38(4): 404-410. [PubMed: 10752972]

Wilson SH, Walker GM. Unemployment and health: a review. Public Health 1993;107(3):153-62. [PubMed: 8511234]

Wooldridge, JM. Econometric Analysis of Cross Section and Panel Data. Cambridge, MA: MIT Press; 2002. 


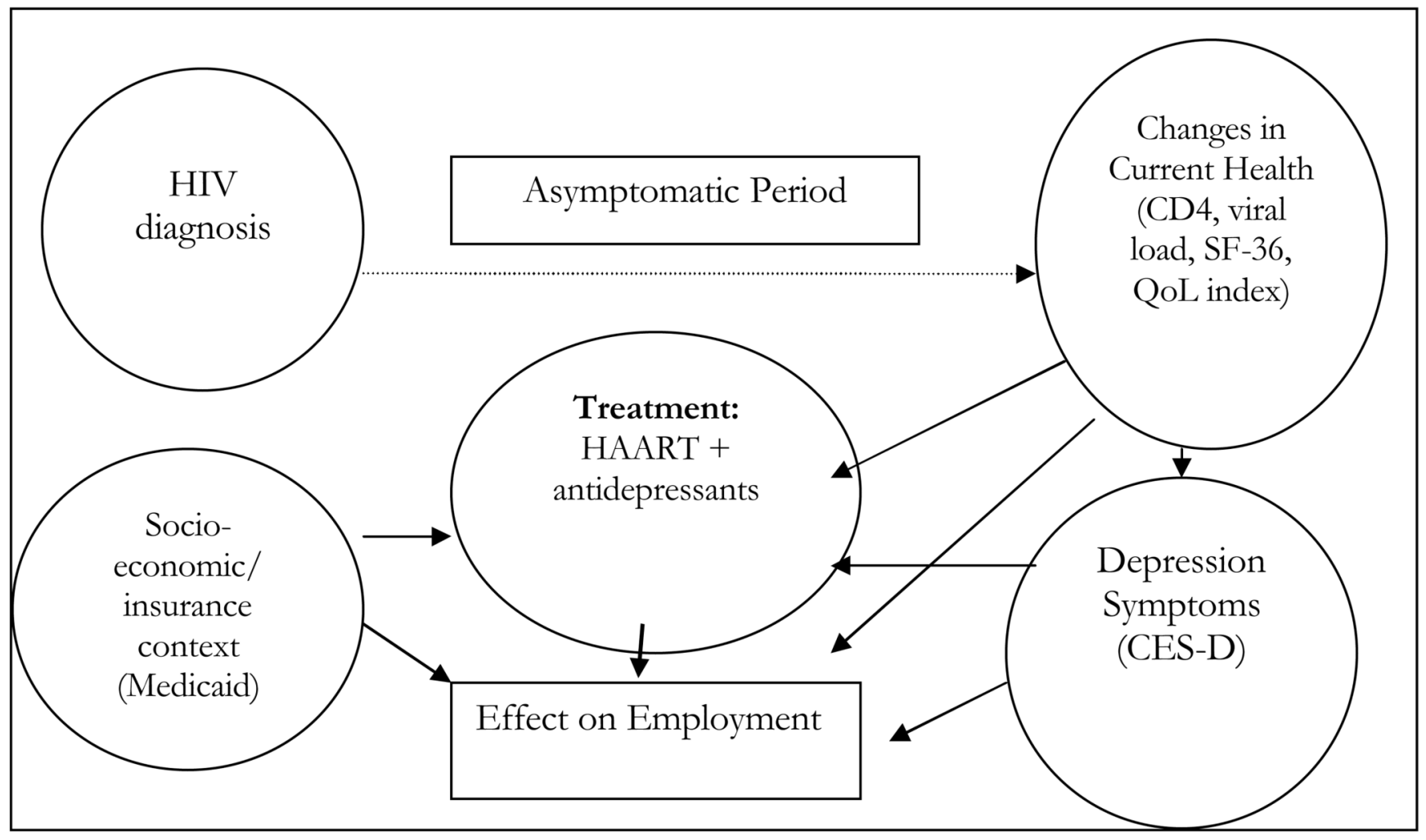

Figure 1.

Conceptual Framework

The Effect of Antidepressant Use on Employment 


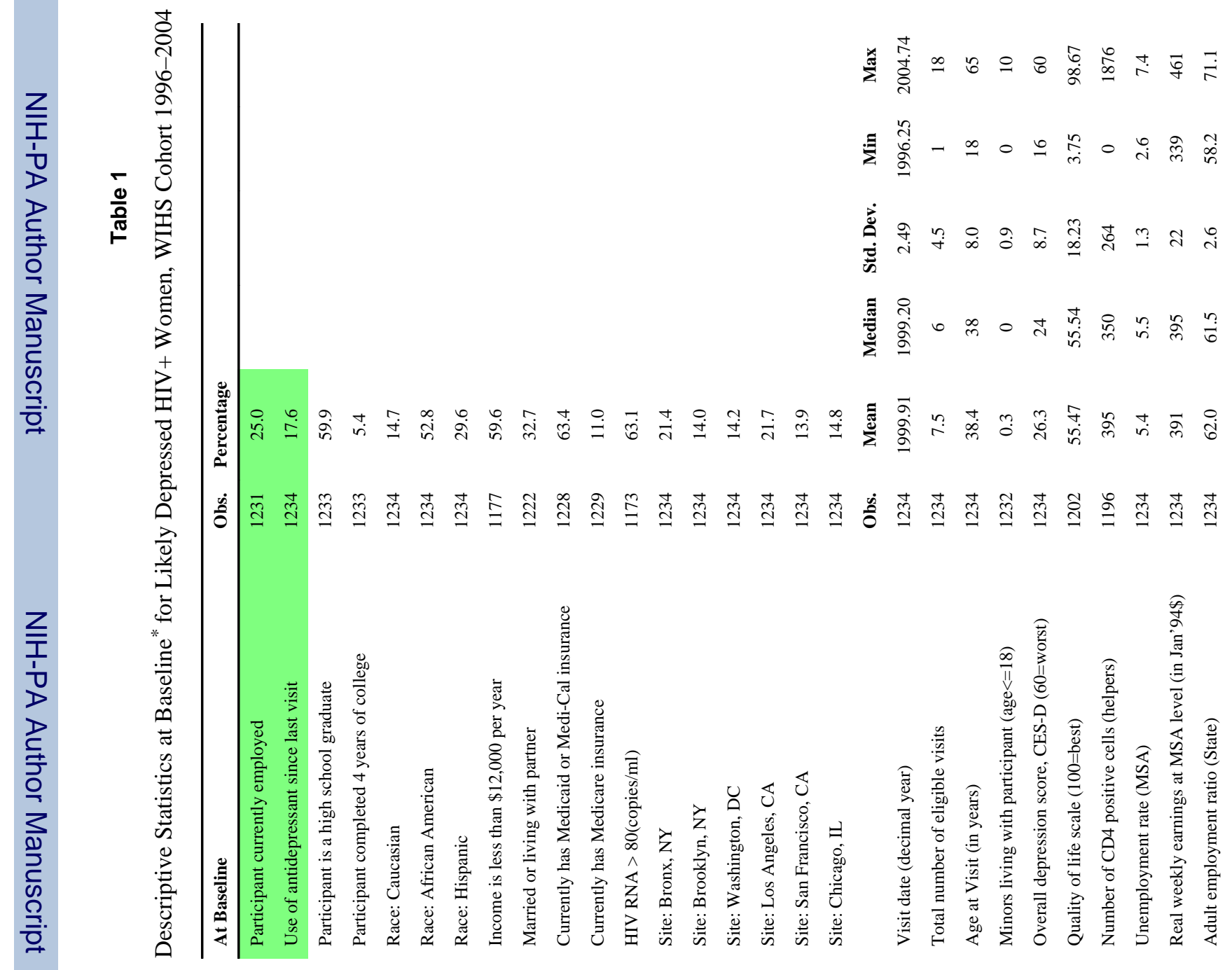




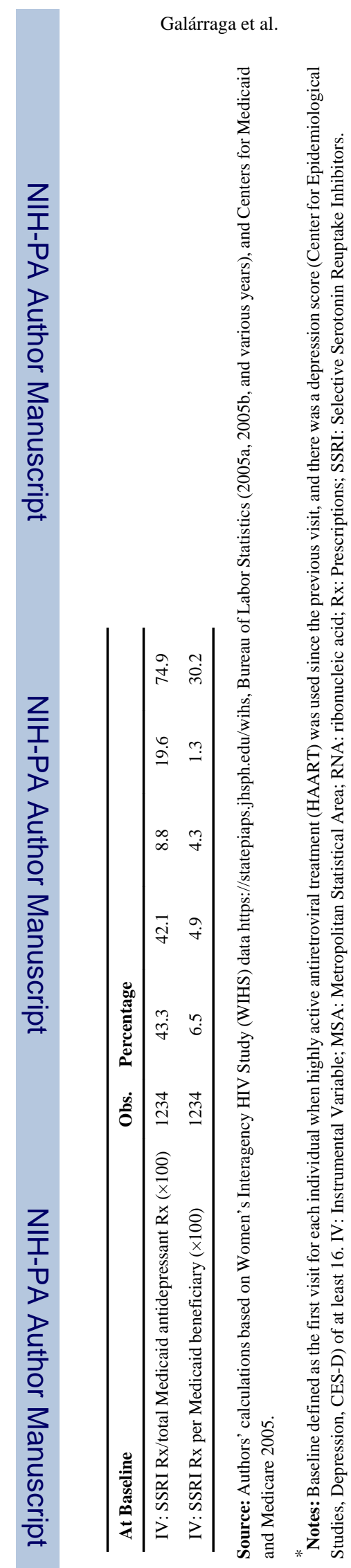

Health Econ. Author manuscript; available in PMC 2010 February 11. 
Table 2

Use of Antidepressants: First Stage Linear Regression Models for Likely Depressed HIV ${ }^{+}$Women, WIHS Cohort 1996-2004

\begin{tabular}{|c|c|c|}
\hline & Random Effects & Fixed Effects \\
\hline IV: SSRI Rx/total Medicaid antidepressant Rx & $\begin{array}{c}0.0041 \\
{[0.0011]^{* *}}\end{array}$ & $\begin{array}{c}0.0047 \\
{[0.0012]^{* *}}\end{array}$ \\
\hline IV: SSRI Rx/Medicaid beneficiary $(\times 100)$ & $\begin{array}{c}0.0084 \\
{[0.0026]^{* *}}\end{array}$ & $\begin{array}{c}0.0094 \\
{[0.0029]^{* *}}\end{array}$ \\
\hline Age (10-year units) & $\begin{array}{c}0.0669 \\
{[0.0762]}\end{array}$ & \\
\hline Age squared & $\begin{array}{c}-0.0057 \\
{[0.0092]}\end{array}$ & \\
\hline High school graduate $(=1)$ & $\begin{array}{c}0.0064 \\
{[0.0187]}\end{array}$ & \\
\hline Race: African American (=1) & $\begin{array}{c}-0.1422 \\
{[0.0250]^{* *}}\end{array}$ & \\
\hline Race: Hispanic (=1) & $\begin{array}{c}-0.1127 \\
{[0.0281]^{* *}}\end{array}$ & \\
\hline Married/living with partner $(=1)$ & $\begin{array}{l}-0.0129 \\
{[0.0138]}\end{array}$ & \\
\hline Minors living at home (ages $<=18$ ) & $\begin{array}{l}-0.0074 \\
{[0.0057]}\end{array}$ & \\
\hline Depression score (CES-D) at $\mathrm{t}-1$ & $\begin{array}{c}0.0012 \\
{[0.0006]}\end{array}$ & $\begin{array}{c}0.0011 \\
{[0.0007]}\end{array}$ \\
\hline Quality of life index $(\times 10)$ at $t-1$ & $\begin{array}{c}-0.0183 \\
{[0.0041]^{* *}}\end{array}$ & $\begin{array}{l}-0.0046 \\
{[0.0050]}\end{array}$ \\
\hline CD4 cell count $(\times 100)$ at $t-1$ & $\begin{array}{c}0.0062 \\
{[0.0027]^{*}}\end{array}$ & $\begin{array}{c}0.002 \\
{[0.0039]}\end{array}$ \\
\hline Viral load > 80 HIV RNA copies per ml at t-1 $(=1)$ & $\begin{array}{c}0.0147 \\
{[0.0131]}\end{array}$ & $\begin{array}{c}0.0057 \\
{[0.0148]}\end{array}$ \\
\hline Unemployment rate (Metropolitan Statistical Area, MSA) & $\begin{array}{c}0.0087 \\
{[0.0081]}\end{array}$ & $\begin{array}{c}0.0144 \\
{[0.0087]^{+}}\end{array}$ \\
\hline Weekly earnings, MSA $(\$ 100 s)$ & $\begin{array}{l}-0.0474 \\
{[0.0341]}\end{array}$ & $\begin{array}{c}-0.0211 \\
{[0.0361]}\end{array}$ \\
\hline Adult employment ratio, State $(\times 10)$ & $\begin{array}{c}0.1325 \\
{[0.0353]^{* *}}\end{array}$ & $\begin{array}{c}0.1314 \\
{[0.0381]^{* *}}\end{array}$ \\
\hline Site: Bronx, NY (=1) & $\begin{array}{c}0.102 \\
{[0.0345]^{* *}}\end{array}$ & \\
\hline Site: Brooklyn, NY (=1) & $\begin{array}{c}0.0293 \\
{[0.0356]}\end{array}$ & \\
\hline Site: Washington, DC $(=1)$ & $\begin{array}{c}0.091 \\
{[0.0446]^{*}}\end{array}$ & \\
\hline Site: Los Angeles, CA (=1) & $\begin{array}{c}0.0776 \\
{[0.0364]^{*}}\end{array}$ & \\
\hline Site: San Francisco, CA (=1) & $\begin{array}{c}0.1904 \\
{[0.0414]^{* *}}\end{array}$ & \\
\hline Observations & 4015 & 4083 \\
\hline Individuals (WIHS ID) & 1045 & 1060 \\
\hline
\end{tabular}

Notes: Table presents coefficients and standard errors [in brackets]: 
$+{ }_{\text {significant at } 10 \% \text {; }}$

* significant at $5 \%$;

**

significant at 1\%. CES-D: Center for Epidemiological Studies-Depression; IV: Instrumental Variable; MSA: Metropolitan Statistical Area; RNA: ribonucleic acid; Rx: Prescriptions; SSRI: Selective Serotonin Reuptake Inhibitors. 
Table 3

Linear Models of Employment Probability for Likely Depressed HIV+ Women, WIHS Cohort 1996-2004

\begin{tabular}{|c|c|c|c|c|}
\hline & \multicolumn{2}{|c|}{ Random Effects } & \multicolumn{2}{|c|}{ Fixed Effects } \\
\hline & Naive OLS & IV & Naive OLS & IV \\
\hline Used antidepressant since $\mathrm{t}-1(=1)$ & $\begin{array}{c}0.0147 \\
{[0.0160]}\end{array}$ & $\begin{array}{c}0.4194 \\
{[0.1532]^{* *}}\end{array}$ & $\begin{array}{c}0.0302 \\
{[0.0177]^{+}}\end{array}$ & $\begin{array}{c}0.2979 \\
{[0.1363]^{*}}\end{array}$ \\
\hline Age (10-year units) & $\begin{array}{c}0.1217 \\
{[0.0864]}\end{array}$ & $\begin{array}{c}0.1159 \\
{[0.0940]}\end{array}$ & & \\
\hline Age squared & $\begin{array}{l}-0.0163 \\
{[0.0104]}\end{array}$ & $\begin{array}{l}-0.0173 \\
{[0.0113]}\end{array}$ & & \\
\hline High school graduate $(=1)$ & $\begin{array}{c}0.1132 \\
{[0.0223]^{* *}}\end{array}$ & $\begin{array}{c}0.1103 \\
{[0.0242]^{* *}}\end{array}$ & & \\
\hline Race: African American(=1) & $\begin{array}{c}-0.1109 \\
{[0.0299]^{* *}}\end{array}$ & $\begin{array}{l}-0.0504 \\
{[0.0386]}\end{array}$ & & \\
\hline Race: Hispanic(=1) & $\begin{array}{l}-0.0482 \\
{[0.0336]}\end{array}$ & $\begin{array}{c}0.0012 \\
{[0.0401]}\end{array}$ & & \\
\hline Married or living with partner $(=1)$ & $\begin{array}{c}0.0206 \\
{[0.0143]}\end{array}$ & $\begin{array}{c}0.0250 \\
{[0.0155]}\end{array}$ & & \\
\hline Minors at home (ages $<=18$ ) & $\begin{array}{c}0.0035 \\
{[0.0057]}\end{array}$ & $\begin{array}{c}0.0023 \\
{[0.0061]}\end{array}$ & & \\
\hline Depression score (CES-D) at t-1 & $\begin{array}{c}-0.0002 \\
{[0.0006]}\end{array}$ & $\begin{array}{c}-0.0003 \\
{[0.0007]}\end{array}$ & $\begin{array}{c}0.0001 \\
{[0.0007]}\end{array}$ & $\begin{array}{c}-0.0000 \\
{[0.0007]}\end{array}$ \\
\hline Quality of life index $(\times 10)$ at $t-1$ & $\begin{array}{c}0.0287 \\
{[0.0042]^{* *}}\end{array}$ & $\begin{array}{c}0.0335 \\
{[0.0050]^{* *}}\end{array}$ & $\begin{array}{c}0.0170 \\
{[0.0049]^{* *}}\end{array}$ & $\begin{array}{c}0.0189 \\
{[0.0051]^{* *}}\end{array}$ \\
\hline CD4 cell count $(\times 100)$ at $t-1$ & $\begin{array}{c}0.0127 \\
{[0.0029]^{* *}}\end{array}$ & $\begin{array}{c}0.0070 \\
{[0.0036]^{*}}\end{array}$ & $\begin{array}{c}0.0081 \\
{[0.0038]^{*}}\end{array}$ & $\begin{array}{c}0.0066 \\
{[0.0040]^{+}}\end{array}$ \\
\hline $\begin{array}{l}\text { Viral load }>80 \text { HIV RNA copies } / \mathrm{ml} \text { at } \\
\mathrm{t}-1(=1)\end{array}$ & $\begin{array}{l}-0.0075 \\
{[0.0133]}\end{array}$ & $\begin{array}{l}-0.0078 \\
{[0.0143]}\end{array}$ & $\begin{array}{c}0.0029 \\
{[0.0144]}\end{array}$ & $\begin{array}{c}0.0023 \\
{[0.0150]}\end{array}$ \\
\hline Unemployment rate (MSA) & $\begin{array}{c}0.0074 \\
{[0.0078]}\end{array}$ & $\begin{array}{l}-0.0002 \\
{[0.0088]}\end{array}$ & $\begin{array}{c}0.0021 \\
{[0.0082]}\end{array}$ & $\begin{array}{l}-0.0035 \\
{[0.0089]}\end{array}$ \\
\hline Weekly earnings, MSA level (\$100s) & $\begin{array}{c}0.0192 \\
{[0.0333]}\end{array}$ & $\begin{array}{c}0.0381 \\
{[0.0364]}\end{array}$ & $\begin{array}{c}0.0137 \\
{[0.0346]}\end{array}$ & $\begin{array}{c}0.0227 \\
{[0.0361]}\end{array}$ \\
\hline $\begin{array}{l}\text { Adult employment ratio, state level } \\
(\times 10)\end{array}$ & $\begin{array}{c}0.0466 \\
{[0.0342]}\end{array}$ & $\begin{array}{c}0.0144 \\
{[0.0390]}\end{array}$ & $\begin{array}{c}0.0630 \\
{[0.0360]^{+}}\end{array}$ & $\begin{array}{c}0.0412 \\
{[0.0389]}\end{array}$ \\
\hline Site: Bronx, NY (=1) & $\begin{array}{c}-0.0895 \\
{[0.0398]^{*}}\end{array}$ & $\begin{array}{c}-0.1203 \\
{[0.0449]^{* *}}\end{array}$ & & \\
\hline Site: Brooklyn, NY (=1) & $\begin{array}{l}-0.0603 \\
{[0.0412]}\end{array}$ & $\begin{array}{l}-0.0637 \\
{[0.0448]}\end{array}$ & & \\
\hline Site: Washington, DC (=1) & $\begin{array}{c}0.1638 \\
{[0.0426]^{* *}}\end{array}$ & $\begin{array}{c}0.1421 \\
{[0.0467]^{* *}}\end{array}$ & & \\
\hline Site: Los Angeles, CA (=1) & $\begin{array}{c}-0.0342 \\
{[0.0371]}\end{array}$ & $\begin{array}{l}-0.0248 \\
{[0.0402]}\end{array}$ & & \\
\hline Site: San Francisco, CA (=1) & $\begin{array}{l}-0.0458 \\
{[0.0428]}\end{array}$ & $\begin{array}{c}-0.0892 \\
{[0.0502]^{+}}\end{array}$ & & \\
\hline Observations & 4011 & 4011 & 4026 & 3793 \\
\hline Number of WIHS participants & 1045 & 1045 & 1048 & 815 \\
\hline
\end{tabular}

Notes: Table presents coefficients and standard errors [in brackets]:

+ significant at $10 \%$; 
* significant at $5 \%$;

**

significant at 1\%. CES-D: Center for Epidemiological Studies-Depression scale; IV: Instrumental Variable; MSA: Metropolitan Statistical Area; OLS: ordinary least squares; RNA: ribonucleic acid. 
Table 4

Probit Models for the Employment Probability of Likely Depressed HIV+ Women, WIHS Cohort 1996-2004

\begin{tabular}{|c|c|c|c|c|}
\hline & \multicolumn{2}{|c|}{ Naive Probit } & \multicolumn{2}{|c|}{ Bivariate Probit } \\
\hline & Coefficient & Marginal Effect & Coefficient & Marginal Effect \\
\hline $\begin{array}{l}\text { Used antidepressants since } \mathrm{t}-1 \\
(=1)\end{array}$ & $\begin{array}{c}0.0524 \\
{[0.0550]}\end{array}$ & $\begin{array}{l}0.0165 \\
{[0.0175]}\end{array}$ & $\begin{array}{c}0.8000 \\
{[0.4248]^{+}}\end{array}$ & $\begin{array}{c}0.2840 \\
{[0.1640]^{+}}\end{array}$ \\
\hline Age (10-year units) & $\begin{array}{c}0.3756 \\
{[0.3223]}\end{array}$ & $\begin{array}{c}0.1169 \\
{[0.1005]}\end{array}$ & $\begin{array}{c}0.5414 \\
{[0.3323]}\end{array}$ & $\begin{array}{c}0.1702 \\
{[0.1044]}\end{array}$ \\
\hline Age squared & $\begin{array}{l}-0.0523 \\
{[0.0385]}\end{array}$ & $\begin{array}{l}-0.0163 \\
{[0.0120]}\end{array}$ & $\begin{array}{c}-0.0718 \\
{[0.0402]^{+}}\end{array}$ & $\begin{array}{c}-0.0226 \\
{[0.0126]^{+}}\end{array}$ \\
\hline High school graduate $(=1)$ & $\begin{array}{c}0.3964 \\
{[0.0778]^{* *}}\end{array}$ & $\begin{array}{c}0.1190 \\
{[0.0223]^{* *}}\end{array}$ & $\begin{array}{c}0.4093 \\
{[0.0826]^{* *}}\end{array}$ & $\begin{array}{c}0.1241 \\
{[0.0236]^{* *}}\end{array}$ \\
\hline Race: African American (=1) & $\begin{array}{c}-0.3643 \\
{[0.0977]^{* *}}\end{array}$ & $\begin{array}{c}-0.1132 \\
{[0.0304]^{* *}}\end{array}$ & $\begin{array}{l}-0.2062 \\
{[0.1271]}\end{array}$ & $\begin{array}{c}-0.0648 \\
{[0.0392]^{+}}\end{array}$ \\
\hline Race: Hispanic (=1) & $\begin{array}{l}-0.1522 \\
{[0.1125]}\end{array}$ & $\begin{array}{l}-0.0463 \\
{[0.0335]}\end{array}$ & $\begin{array}{l}-0.0878 \\
{[0.1329]}\end{array}$ & $\begin{array}{l}-0.0273 \\
{[0.0405]}\end{array}$ \\
\hline $\begin{array}{l}\text { Married or living with a partner } \\
(=1)\end{array}$ & $\begin{array}{c}0.0795 \\
{[0.0539]}\end{array}$ & $\begin{array}{c}0.0250 \\
{[0.0172]}\end{array}$ & $\begin{array}{c}0.1198 \\
{[0.0673]^{+}}\end{array}$ & $\begin{array}{c}0.0383 \\
{[0.0219]^{+}}\end{array}$ \\
\hline Minors at home (ages $<=18$ ) & $\begin{array}{c}0.0161 \\
{[0.0201]}\end{array}$ & $\begin{array}{c}0.0050 \\
{[0.0063]}\end{array}$ & $\begin{array}{l}-0.0003 \\
{[0.0281]}\end{array}$ & $\begin{array}{l}-0.0001 \\
{[0.0088]}\end{array}$ \\
\hline $\begin{array}{l}\text { Depression score (CES-D) at } \\
\mathrm{t}-1\end{array}$ & $\begin{array}{l}-0.0003 \\
{[0.0021]}\end{array}$ & $\begin{array}{l}-0.0001 \\
{[0.0007]}\end{array}$ & $\begin{array}{c}-0.004 \\
{[0.0029]}\end{array}$ & $\begin{array}{l}-0.0012 \\
{[0.0009]}\end{array}$ \\
\hline Quality of life index $(\times 10)$ at $t-1$ & $\begin{array}{c}0.1033 \\
{[0.0163]^{* *}}\end{array}$ & $\begin{array}{c}0.0321 \\
{[0.0051]^{* *}}\end{array}$ & $\begin{array}{c}0.1713 \\
{[0.0204]^{* *}}\end{array}$ & $\begin{array}{c}0.0538 \\
{[0.0067]^{* *}}\end{array}$ \\
\hline CD4 cell count $(\times 100)$ at $t-1$ & $\begin{array}{c}0.0428 \\
{[0.0102]^{* *}}\end{array}$ & $\begin{array}{c}0.0133 \\
{[0.0032]^{* *}}\end{array}$ & $\begin{array}{c}0.0452 \\
{[0.0147]^{* *}}\end{array}$ & $\begin{array}{c}0.0142 \\
{[0.0045]^{* *}}\end{array}$ \\
\hline $\begin{array}{l}\text { Viral load> } 80 \text { HIV RNA } \\
\text { copies/ml at t-1 }(=1)\end{array}$ & $\begin{array}{l}-0.0289 \\
{[0.0488]}\end{array}$ & $\begin{array}{l}-0.0090 \\
{[0.0152]}\end{array}$ & $\begin{array}{l}-0.0875 \\
{[0.0623]}\end{array}$ & $\begin{array}{l}-0.0277 \\
{[0.0199]}\end{array}$ \\
\hline Unemployment rate (MSA) & $\begin{array}{c}0.0239 \\
{[0.0282]}\end{array}$ & $\begin{array}{c}0.0074 \\
{[0.0088]}\end{array}$ & $\begin{array}{c}0.0268 \\
{[0.0341]}\end{array}$ & $\begin{array}{c}0.0084 \\
{[0.0106]}\end{array}$ \\
\hline $\begin{array}{l}\text { Weekly earnings, MSA } \\
(\$ 100 \text { s) }\end{array}$ & $\begin{array}{c}0.0725 \\
{[0.1188]}\end{array}$ & $\begin{array}{c}0.0226 \\
{[0.0370]}\end{array}$ & $\begin{array}{c}0.1248 \\
{[0.1367]}\end{array}$ & $\begin{array}{c}0.0392 \\
{[0.0431]}\end{array}$ \\
\hline $\begin{array}{l}\text { Adult employment ratio, State } \\
(\times 10)\end{array}$ & $\begin{array}{c}0.1615 \\
{[0.1085]}\end{array}$ & $\begin{array}{c}0.0503 \\
{[0.0339]}\end{array}$ & $\begin{array}{c}0.1065 \\
{[0.1351]}\end{array}$ & $\begin{array}{c}0.0335 \\
{[0.0423]}\end{array}$ \\
\hline Site: Bronx, NY (=1) & $\begin{array}{c}-0.3086 \\
{[0.1346]^{*}}\end{array}$ & $\begin{array}{c}-0.0894 \\
{[0.0359]^{*}}\end{array}$ & $\begin{array}{c}-0.3933 \\
{[0.1403]^{* *}}\end{array}$ & $\begin{array}{c}-0.1129 \\
{[0.0366]^{* *}}\end{array}$ \\
\hline Site: Brooklyn, NY (=1) & $\begin{array}{l}-0.1931 \\
{[0.1369]}\end{array}$ & $\begin{array}{l}-0.0572 \\
{[0.0384]}\end{array}$ & $\begin{array}{c}-0.2954 \\
{[0.1445]^{*}}\end{array}$ & $\begin{array}{c}-0.086 \\
{[0.0385]^{*}}\end{array}$ \\
\hline Site: Washington, DC (=1) & $\begin{array}{c}0.4730 \\
{[0.1402]^{* *}}\end{array}$ & $\begin{array}{c}0.1628 \\
{[0.0519]^{* *}}\end{array}$ & $\begin{array}{c}0.3272 \\
{[0.1564]^{*}}\end{array}$ & $\begin{array}{c}0.1107 \\
{[0.0557]^{*}}\end{array}$ \\
\hline Site: Los Angeles, CA (=1) & $\begin{array}{l}-0.1026 \\
{[0.1231]}\end{array}$ & $\begin{array}{l}-0.0313 \\
{[0.0368]}\end{array}$ & $\begin{array}{l}-0.1225 \\
{[0.1331]}\end{array}$ & $\begin{array}{l}-0.0377 \\
{[0.0399]}\end{array}$ \\
\hline Site: San Francisco, CA (=1) & $\begin{array}{l}-0.1489 \\
{[0.1417]}\end{array}$ & $\begin{array}{l}-0.0444 \\
{[0.0404]}\end{array}$ & $\begin{array}{l}-0.2154 \\
{[0.1582]}\end{array}$ & $\begin{array}{l}-0.0636 \\
{[0.0442]}\end{array}$ \\
\hline Value of $\rho$ & & & $\begin{array}{c}-0.4718 \\
{[0.2777]^{+}}\end{array}$ & \\
\hline Observations & 4011 & & 4011 & \\
\hline Clusters (WIHS ID) & 1045 & & 1045 & \\
\hline
\end{tabular}

Notes: Table presents coefficients and standard errors [in brackets]: 
$+{ }_{\text {significant at } 10 \% \text {; }}$

* significant at $5 \%$;

**

significant at 1\%. CES-D: Center for Epidemiological Studies-Depression scale; MSA: Metropolitan Statistical Area; RNA: ribonucleic acid. 